\title{
FROM OUTLINING TO ACADEMIC WRITING
}

\author{
I Made Wardhana \\ STIPAR Triatma Jaya, Badung
}

\begin{abstract}
Academic essay writing undergoing the process of pre-writing, drafting, responding, revision, editting and post writing showing that it is not a simple activity, therefore it requires techniques or ways to help the writer, especially a beginner writer in expressing one's ideas to write an academic writing. This study attempted to find out whether outlining could enhance the efficiency for the students to write an academic essay. The responses to the questionnaires distributed to 115 students showed that outlining could make it easier for them to write academic essay writing especially in organising their ideas. The result of product moment computation also confirmed that there was a very positive correlation between the students' perception on outlining and their academic essay writing achievement. Therefore, it could be suggested that during the prewriting stage the students should be exposed with the process of writing outline so their writing would be more focussed on the topic idea of the thesis statement and topic ideas of the topic sentences with a good development of ideas and sentences in order to get a unified and coherent writing.
\end{abstract}

Keywords: outlining, academic essay writing, thesis statement, topic sentence

\begin{abstract}
ABSTRAK
Penulisan akademik yang kompleks melalui tahapan seperti pratulis, drafting, tanggapan, revisi, pengeditan, dan pasca-tulis menunjukkan kegiatan penulisan akademik bukanlah hal yang mudah. Oleh karena itu diperlukan adanya teknik maupun cara yang dapat pembantu penulis (khususnya penulis essei akademik pemula) memudahkan mereka dalam mengekpresikan ide-idenya dalam tulisan akademik. Penelitian ini mencoba untuk menemukan jawaban permasalahan apakah outlining dapat mempermudah penulisan akademik. Hasil kwesioner dari 115 mahasiswa menunjukkan bahwa outlining dapat memudahkan mereka untuk menulis penulisan akademik secara lebih baik khususnya dalam pengorganisasian ide-ide mereka. Hasil komputasi product moment juga menunjukkan terdapat korelasi sangat positip antara persepsi mahasiswa terhadap outlining dengan hasil penulisan akademik mahasiswa. Sehingga dapat disarankan dalam tahapan pratulis mahasiswa supaya diekspos dengan proses penulisan outlining sehingga tulisannya bisa lebih berfokus pada ide-ide topik dalam thesis statement maupun dalam topic sentences dengan developing ideas yang cermat untuk memperolah tulisan yang coherent dan unified.
\end{abstract}

Keywords: Outlining, penulisan essei akademik, thesis statement, topic sentence 


\section{Background}

Academic writing is such complex processes of activities, pre-writing, drafting, responding, revising, editing, and post-writing (Widodo, 2008) that requires an integrated capability to do as they involve the mastery of various aspects of language such as structure, grammar, vocabulary, spelling, and of course, ideas, mechanics as well as how to organize and finalize them in a real product of writing, for example, a composition or an essay. This may have made writing as one of the most difficult skills among other language skills. No wonder, writing or more specifically academic writing may relatively become a subject of "a nightmare" for the students. According to Britton (1970) such writing tends to be serious in nature and often demonstrate particular theories or arguments in relation to specific discourse.

As a teacher of Academic writing, the writer found it curious to know any means to assist the learners to make it easier for them to write, especially on academic English writing as it is one of the requirements for them to write their final assignment, a thesis or a research report which is admitted as an important skill to teach for university students (Ganobscik Williams, 2004: .28). Although the fact shows that no wonder grammar puts its first place on the problems the students encounter in writing academic writing, organising ideas and thought might be another serious problem the students face. Therefore, experience seems to show that outlining might be the solution to help students write more systematically.

This study, to support widodo's (2008) study on process based academic writring, in this case, prewriting, intended to find out the position of outlining in the process to the academic writing achievement.

\section{Theoretical Background}

Widodo's (2008) study on Process-based academic essay writing instruction in an EFL context showed that within the process-based framework,

writing is viewed as process which involves pre-writing, drafting, responding, revising, editing, and post-writing through which students recursively and reflectively reel.

Outlining, as a pre writing activity, is a formal system used to think about and 
organize a paper. For example, it can be used to see whether the ideas are connected to each other, what order of ideas works best, or whether there is sufficient evidence to support each of the points. Outlines can be useful for any paper to help see the overall picture.

Whitaker (2009: 7) suggested that basic outline can be made after the thesis statement is already determined to ensure that the writing is focused on the thoughts and well organized to focus and organize the research as well as to help order the ideas.

There are two kinds of outlines: the topic outline and the sentence outline (Oshima and Hogue, 2007: 160). The topic outline consists of short phrases which is particularly useful when you are dealing with a number of different issues that could be arranged in a variety of ways in the paper. The sentence outline is done in full sentences. It is normally used when the paper focuses on complex details. The sentence outline is especially useful for this kind of paper because sentences themselves have many of the details in them. A sentence outline also allows the writer to include those details in the sentences instead of having to create an outline of many short

phrases that goes on page after page. Both topic and sentence outlines follow rigid formats, using Roman and Arabic numerals along with capital and small letters of the alphabet. This helps both the writer and the readers follow the organization of the essay more easily. This is the kind of outline most commonly used for classroom papers and speeches as shown in Table 1.

\section{Table 1}

\section{An Example of An Outline Format}

\section{Introduction}

Thesis statement

II. Body
A. Topic Sentence
1. Main Supporting Point
a. Supporting Detail
b. Supporting Detail
2. Main Supporting Point
a. Supporting Detail
b. Supporting Detail
3. Main Supporting Point
a. Supporting Detail
b. Supporting Detail

B. Topic Sentence

1. Main Supporting Point
a. Supporting Detail
b. Supporting Detail
- 2. Main Supporting Point
a. Supporting Detail
b. Supporting Detail

Ill. Conclusion

Oshima, Alice and Hogue, Ann (2007:

159) 
According to Oshima (2007) there is no rule for which type of outline is best. The writer is supposed to choose the one that is thought to work best for any particular type of writing.

The followings are worth considering in making an outline.

1. The topic must be identified. The topic of the paper is important. The point of the paper must be summerized in one sentence or phrase. This will help it stay focused on the main point.

2. The main categories must be identified such as what main points will be covered. The introduction usually introduces all of the main points, then the rest of paper can be spent developing those points.

3. The first category is created and followed by what the first point is to be covered. If the paper centers around a complicated term, a definition is often a good place to start. For a paper about a particular theory, giving the general background on the theory can be a good place to begin.

4. Subcategories are created after the mainpoints are obtained, then the points are provided to support the main point. The number of categories used depends on the amount of information which is going to be covered; there is no fix rules about the number of categories. By convention, each category consists of a minimum of two entries. If the first category starts with roman numeral, the outline must also be consistent to use a category of roman numeral. Hence, if there is a capital letter A under category I, there must also be followed by a capital letter B. Then, there could be capital letters C, D, E, etc. depending on the amount of sub-points which are going to be covered. The requirement is to have only at least two of each numbered or lettered category.

5. The out line is better to be flexible. Although the format of an outline is rigid, it should make it flexible to write the paper. In case, the subject to write is something new, it is possible to modify the outline just as making corrections on a crude map since it is is more familiar with the terrain being explored.. Major reorganization is not uncommon; the outline will help stay organized and focused.( University of Washington Psychology Writing Center http://www.psych.uw.edu/psych.php\#p= 339)

According to Oshima and Houge (2007: 15) the process of writing roughly 
undergoes four steps, prewriting, organising, writing and revising. The first step is the way to get the ideas for explaining the topic. Listing can be one technique to collect as many ideas under the topic which is already decided and keep going on listing until there are enough words or phrases to support the topic. Next is to organise the words or phrases into an outline. Then, the rough draft can be written from the ideas and information from the list without considering the grammatical errors. Any additional ideas which come in minds can be added and use the outline as a guide and give the conclusion at the end of the paragraph. The rough draft needs revising and polishing with its grammar, punctuation and mechanics. The revision and editition can be done by peers' help. Additionally Whitaker (2009) suggests 9 steps which are choosing a topic, thinking or brainstorming, researching, discovering thesis statement, outlining, writing, revising, editing and proofreading. However, for class purpose, the four steps suggested by Oshima would be proper.

\section{Population and Sample}

Since this investigation was a kind of semi classroom action research and exposs- pacto in which the writer was the teacher himself, the population taken were all Semester V Classes and the samples were class G, H, I, J students where the writer teaches academic writing in the academic year 2014/2015. There were 34 students of Class G, 24 students of Class $\mathrm{H}, 30$ students of Class $\mathrm{I}$ and 30 students of Class $\mathrm{J}$ on The Attendance Lists. Apart from that for the sake of efficiency, Classes G, H, I, J were selected on purpose because the writer himself taught Writing IV (Academic Writing) to these students but not to other 6 other Classes of Semester $\mathrm{V}$ students so academically the writer knew the students better than the others and quantitatively as the sample of the research, those were considered representative as they were more than 15 to 25 per cent of the population (Suharsimi 2002).

\section{Instrumentation}

The insruments used in this study was a questionnairre and a test. The questionnaire was distributed to get 
information about the students' responses on their preferences or reactions or perception towards the activities of writing in academic writing. The test was conducted as a pretest which was to write a free topic essay writing beginning with an outline and post test of essay writing also beginning with outline; the data of questionnaire responses would be confronted with the students's achievement in academic writing after being exposed to academic writing exercises beginning with outlining to find out the correlation between the students' perception on outlining and their academic writing achievement. Moreover, the students were already exposed with outlining every time they wrote an essay.

\section{Procedures of Data Collection}

The data obtained from the questionnaires would be calculated to find the percentage of positive and negative responses of the students on outlining.

As this investigation was, the writer would say, a semi classroom action research and ex post pacto in its nature which is a kind of applied research to examine a specific issue (Goodenough
2011: 4) conducted in the classroom by the teacher in order to improve or solving the problems of teaching learning process (Elisabeth, in Burns 2010:5) carried out in only one cycle depending on the improvement of the teaching learning process. The data of which were made about the new knowledge through conclusion drawn from validated evidence (Mc Niff and Whitehead 2002: 16). Outline is considered to be an important aspect of teaching academic writing, particularly in improving the students' capability to organise a unified and coherent essay.

The teaching learning process started by choosing a topic, thinking or brainstorming, researching, discovering thesis statement before they were exposed with the process of making an outline. Next, they continued with writing components of academic essay such as introductory paragraph with its thesis statement with its topic ideas, developing paragraphs with their transitional signals/words/sentence, cohesive devices and finalised with the conclusion.

Therefore, the procedures of data collection were as follows. After they were exposed with the process of 
academic writing following the four steps (Oshima and Hogue, 2007), they were supposed to respond to a Likert's (1932) scale of five categories questionnaire which is also supplied with open questions (Dwyer, 2000: 86) (see Appendix) which showed the positive and negative perception of the students' towards outlining. Next, after they already learned how to write academic essay they were given a test of writing an academic essay from a number of provided optional thesis statements to find out their writing achievement especially in organizing ideas through their outline. Then, the average score of every sample on all questionnaire items were confronted with their achievement in academic writing to find out the correlation between their perception and their writing achievement.

\section{Findings and Discussions}

As the questionnaire comprised positive and negative types of questions (see Table1), expecting to get more objective respons, the data of which were treated properly so as to show the appropriate perception. In other words, the positive respons to the positive items (items
$1,3,5,7,8,9,11,13,15)$ were treated as positive perceptions; on the other hand, the negative respons to the negative items $(2,6,10,14)$ as positive perceptions. The result showed in general that the students had very positive responns $(82.73 \%$, Table 1$)$ on the use of outline before they started to write the essay. Responding on its benefit, outline made it esier for them to write an essay (97\%), easier to organise ideas (93\%), easier to remember ideas selected from brainstorming (96\%). Additionally, contrasting the items into negative statements, $75 \%$ disagreed to the statement that they didn't understand how to write an outline; $74 \%$ disagreed to the statement that without outline they could write an essay easily; $72 \%$ to " without outlining ideas and information were easy to remember to make it easier for them to write smoothly"; when responding to the comprehension on the component of outline, $85 \%$ disgreed to the statemement "there is no need to include thesis statement, topic ideas and supporting ideas in the outline". Moreover, on suggesting the use of outline in writing academic essay, $80 \%$ responded that the students had to write an outline before writing the essay. 
However, when confronted with the statement "outline could be in sentences, phrases or words" only $71 \%$ have positive responses. Presumably they were doubtful whether the outline could be in sentences or not due to unclear exposure from the teacher as the teacher only emphasized the use of outline only in phrases and words.

Table 1

Percentage of the Students' answers on the questionnaire for each item

\begin{tabular}{|c|c|c|c|c|c|c|c|c|c|}
\hline $\begin{array}{c}\text { No of } \\
\text { Item }\end{array}$ & $\begin{array}{l}\mathrm{A} \\
\%\end{array}$ & $\begin{array}{l}\mathrm{B} \\
\%\end{array}$ & $\begin{array}{l}\mathrm{C} \\
\%\end{array}$ & $\begin{array}{l}\mathrm{D} \\
\%\end{array}$ & $\begin{array}{l}\mathrm{E} \\
\%\end{array}$ & $\begin{array}{l}\text { Posi } \\
\text { tive }\end{array}$ & $\begin{array}{c}\text { Nega } \\
\text { tive }\end{array}$ & $\begin{array}{c}\mathrm{Neu} \\
\text { tral }\end{array}$ & $\begin{array}{c}\mathrm{Re} \\
\text { mark }\end{array}$ \\
\hline 1 & 55 & 42 & 3 & 0 & 0 & 97 & 0 & 3 & \\
\hline 3 & 18 & 56 & 22 & 4 & 0 & 74 & 4 & 22 & \\
\hline 4 & 58 & 33 & 7 & 2 & 0 & 91 & 2 & 7 & \\
\hline 5 & 39 & 50 & 10 & 1 & 0 & 89 & 1 & 10 & \\
\hline 7 & 48 & 48 & 3 & 1 & 0 & 96 & 1 & 3 & \\
\hline 8 & 45 & 41 & 13 & 1 & 0 & 86 & 1 & 13 & \\
\hline 9 & 54 & 39 & 5 & 2 & 0 & 93 & 2 & 5 & \\
\hline 11 & 31 & 54 & 9 & 6 & 0 & 85 & 9 & 6 & \\
\hline 13 & 41 & 39 & 19 & 1 & 0 & 80 & 1 & 19 & \\
\hline 15 & 20 & 51 & 17 & 12 & 0 & 71 & 12 & 17 & \\
\hline 2 & 1 & 15 & 10 & 46 & 28 & 74 & 16 & 10 & \\
\hline 6 & 3 & 9 & 15 & 47 & 26 & 73 & 12 & 15 & \\
\hline 10 & 4 & 13 & 11 & 43 & 29 & 72 & 17 & 11 & \\
\hline 12 & 1 & 4 & 20 & 47 & 28 & 75 & 5 & 20 & \\
\hline 14 & 3 & 5 & 7 & 36 & 49 & 85 & 8 & 7 & \\
\hline \multicolumn{6}{|c|}{ Percentage of Average Total scores } & 82.73 & 6.06 & 11.2 & \\
\hline
\end{tabular}

Concerning the reasons of their positive responses towards outlining (see Table 2), $92.3 \%$ said that they understood what outline since, according to them (61\%), the teacher already explained it giving the steps and examples of how to write an essay outline and $16.5 \%$ focussed their mind on the thesis statement and it was esier for them to write through a framework(13.5\%) as well as easier to get ideas for the essay (9\%). However, from those who said that they did not undestand outline, $11.7 \%$ admitted that they were still confused about it.

With regard to the parts of outline which helped them write an essay they said that brainstorming helped them get as many ideas from the topic ideas in the thesis 
statement(51\%) ; topic ideas can reminded them to remain focuss on the context of elaboration of ideas in accordance with the thesis statement $(46 \%)$; and cohesive devices such as personal and impersonal pronouns can help the essay remain unified and coherent (3\%). Furthermore, being encoutered with the question of the necessity of outline They almost absolutely agree that the the sudents have to write an outline before writing an academic essay(94\%) giving the reason making it easier for them to develop ideas(78\%) because they stick on the thesis statement (22\%); however, 6 per cent still believed that they could write an essay without an outline because it was confusing for them which could happen presumably because they were absent during the class'outlining exposure.

Organising the essay was considered the most absolute help (100\%) that outlining could offer in writing an academic essay, certainly because their ideas would be more organised so it was easier to read and understand as well as faster for them to develop the ideas from the topic sentences and thesis statement.

Table 2

Frequencies of Students' answers on open-ended questions on Outlining

\begin{tabular}{|l|l|c|c|l|}
\hline $\begin{array}{l}\text { Question } \\
\text { No }\end{array}$ & The Students' & $\begin{array}{l}\text { Freq } \\
\text { uency }\end{array}$ & $\begin{array}{l}\text { Percen } \\
\text { tage }\end{array}$ & Remark \\
\hline \multirow{3}{*}{ Responses and reasons } & Understand about outline & 109 & 92.3 & Positive \\
& $\begin{array}{l}\text { Reason: } \\
\text { - The teacher explains it giving the }\end{array}$ & 59 & 61 & \\
& Steps and examples of writing an outline & 16 & 16.5 & \\
& $-\quad$ focusing on the thesis statement & 13 & 13.5 & \\
& $-\quad$ easier to write from a frame work & 9 & 9 & \\
& $-\quad$ esier to get ideas for the essay & 13 & 11.7 & negative \\
& Do not understand an outline & & & \\
& Reason: & & & \\
& $-\quad$ Still doubtful and confused about & & & \\
& an outline & & & \\
\hline
\end{tabular}




\begin{tabular}{|c|c|c|c|c|}
\hline b. & $\begin{array}{l}\text { Things in the outline which help to write } \\
\text { an essay: } \\
\text { - The ideas to develop from } \\
\text { brainstorming } \\
-\quad \text { Topic ideas in the thesis } \\
\text { statement } \\
-\quad \text { Cohesive devices }\end{array}$ & $\begin{array}{c}47 \\
43 \\
3\end{array}$ & $\begin{array}{c}51 \\
46 \\
3\end{array}$ & positive \\
\hline $\mathrm{C}$ & $\begin{array}{l}\text { Necessity to write an outline } \\
\text { Reason: } \\
\text { - easier to write and develop ideas } \\
\text { - Stay focussed on the thesis statement } \\
\text { - it's easier to write without outline } \\
\text { because of confusion }\end{array}$ & $\begin{array}{c}100 \\
78 \\
22 \\
3\end{array}$ & $\begin{array}{c}94 \\
78 \\
22 \\
6\end{array}$ & Positive \\
\hline $\mathrm{D}$ & $\begin{array}{l}\text { Organization } \\
\text { More organized } \\
\text {-easier and faster to develop ideas }\end{array}$ & $\begin{array}{c}100 \\
76 \\
24\end{array}$ & $\begin{array}{c}100 \\
76 \\
24\end{array}$ & positive \\
\hline
\end{tabular}

To assert the influence of the students' perception on outlining and their academic writing achievement, it's necessary to find out the correlation between the outline and the students'achievement in acadmic writing, in this case, using Pearson's product moment conversion correlation fomula:

$$
r x y=\frac{N \cdot \Sigma X Y-(\Sigma X)(\Sigma Y)}{\sqrt{\left.\left\{N \cdot \Sigma X^{2}-(\Sigma X)^{2}\right\}\left(N . \Sigma Y^{2}\right)-(\Sigma Y)^{2}\right\}}}
$$

In which $\mathrm{N}$ is the number of respondents

$\mathrm{X}$ is the students' perception on outlining

$\mathrm{Y}$ is the students' achievement on academic writing (emphsized on organizing academic writing)

The tabulation looks like Table 3 (See Appendix 1) as the following 


$$
\begin{aligned}
& r x y=\frac{N \cdot \Sigma X Y-(\Sigma X)(\Sigma Y)}{\sqrt{\left.\left\{N \cdot \Sigma X^{2}-(\Sigma X)^{2}\right\}\left(N \cdot \Sigma Y^{2}\right)-(\Sigma Y)^{2}\right\}}} \\
& \mathrm{X} \text { is }=472.667 \\
& \mathrm{Y} \text { is }=476.5 \\
& \mathrm{X}^{2} \text { is }=1969.41333 \\
& \mathrm{Y}^{2} \text { is }=2063.75 \\
& \mathrm{XY} \text { is }=2002.6 \\
& \mathrm{~N} \quad=115 \\
& r x y=\frac{115.2002,6-(472,67)(476,5)}{\sqrt{\left.\left\{115.1969,413-(472,667)^{2}\right\}(115.2063,75)-(476,5)^{2}\right\}}} \\
& =0,903
\end{aligned}
$$

Therefore, Rxy is $\quad 0,903$

To interprate the value of $\mathrm{Rxy}$, the scores must firstly be squared in order to get the value $\mathbf{0 . 9 0 3}$ The closer the value $\mathrm{Rxy}^{2}$ to figure 1 shows that there is a stronger correlation of both variables. On the contrary, the closer the value to figurre 0 the weaker the correlation is. If the value of Rxy is positive it means that both variables have linear correlation but if the value of Rxy is negative the correlation is negative or contradictory (Eko Budiarto, 2001: 248). Therefore, the value of $\mathrm{Rxy}=\mathbf{0 . 9 0 3}$ shows that there is a very positive correlation between the students' perception on outlining and their English academic essay writing achievement.

The positive linear value of variable $X($ perception) and variable $\mathrm{Y}$ (achievement) also shows that the higher the students'perception on outlining the higher their writing achievements is.

\section{Conclusions and Suggestions}

Although the students agree that Writing is the most difficult English skill subjects (Walk, 2007:1; Wardhana, 2011) and one of the most important subjects involving such complex processes of activities of pre-writing, drafting, responding, revising, editing, and post-writing (Widodo, 2008), this study posed the following conclusions.

1. The students had a positive perception about outlining in academic writing in which $82.73 \%$ agreed to make an outline before they did the process of writing because it's esier for them to 
write, especially in organizing the essay and focussing the developing sentences and paragraph on the thesis statement.

2. The students' achievement on academic writing was good (average score of 4.14) especially in essay organization.

3. There was high correlation between the students' perception on outlining and their writing achievement ( 0.903 of product moment)

4. Putting forward their opinion for the reasons they prefered to use outlining, the students said that the teacher explained how to write the outline by explaining the steps and giving examples of brainstorming the topic ideas of the thesis statement as well as writing the essay.

It's the time to focus the teaching of writing not only on the product or what the students produce but also on the process or how they produce it. As outlining is significant to improve the academic writing achievement, the study put forward the following suggestions.

1. Apart from the capaility of the smart ones, outline was still very helpful for majority of the students to organize ideas in sentences and paragraphs, therefore, this study suggested that outline could be the priority option in writing English academic essay.

2. In line with Widodo's (2008) complex processes of academic writing, despite a lot of time needed, outlining steps such as determining thesis statement, topic ideas, brainstorming ideas, organising ideas and drafting should be included in the pre academic writing activities.

\section{References}

Bruce, I. 2008. Academic Writing and Genre A Systematic Analysis New York: Continum.

Budiarto, E. 2001. Biostatistika. Jakarta: Penerbit Buku Kedokteran EG.

Burn, A. 2010. Doing Action Research in English Language Teaching. New York: Routledge.

Coffin, C. 2003. Teaching Academic Writing. New York: Routledge.

Cohen, L., et al. 2007. Research Methods in Education. Sixth Edition. New York: Routledge.

Goodenough, K. 2011. Taking Action in Science Classroom through Collaborative Action Research. Rotterdam: Sense Publishers.

Likert, R. 1932. The Value of Likert scales in Measuring attitude of online learners. Downloaded from www.hkadesigns.co.uk/websites/ms c/reme/likert.htm.

McNiff, J. and Whitehead, J. 2002. Action Research: Principles and Practice. New York: Routledge. 
Oshima, A. and Hogue, A. 2007. Introduction to Academic Writing. New york: Pearson Education, Inc.

Suharsimi, A. 2002. Prosedur Penelitian: Suatu Pendekatan Praktek. Edisi Revisi. Jakarta: Renika.

Wardhana, I M. 2012. The Students' Perspective on Academic Writing and Their Writing Achievement. Jurnal Santiaji Pendidikan, No. 2 vol. 1 hal. $1-13$.

Widiantini, R. 2012. Improving Reading Comprehension through Word Omission Technique to Eight Grade Students of SMP Panca sila, Canggu 2011/2012. Unpublished Thesis.

Widodo, H. P. 2008. Process-based Academic Essay Writing Instruction in an EFL Context. IKIP Negeri Malang: Jurnal Bahasa dan Seni Tahun 36, Nomor 1.

2003 Outlining your scholarly paper The Writing Center at GULC. George Town University

1997 How to write an Outline. University of Washington Psychology Writing Center http://www.psych.uw.edu/psych.php $\# \mathrm{p}=339 \quad$ Box 351525

psywc@uw.edu. $1995 B B C$ ENGLISH: TEACHERS' SUPPLEMENT March page 7 . 